\title{
ANNOUNCEMENT and CALL FOR PAPERS
}

\section{THE THIRD INTERNATIONAL CONGRESS OF BIORHEOLOGY}

28 August-1 September 1978

La Jolla (San Diego), California, U.S.A.

ORGANIZING COMMITTEE OF THE THIRD INTERNATIONAL

Chairman: Yuan-Cheng Fung CONGRESS

Secretary General: John Pinto

Technical exhibition: Larry Malcom

Treasurer: Savio Woo

Finance: Sidney Sobin

Ladies Program: Luna Fung

Local Arrangements: Michael Yen, Chairman

Nancy Bingham, Peter Chen

David Hu, Eugene Mead, Paul Zupkas.

\section{SCIENTIFIC PROGRAM}

The scientific program will include symposia of invited lectures and sessions for contributed papers.

1. Molecular forces in the mechanics of cell membrane

2. Recent advances in hemorheology

3. Properties of biosolids

4. Rheology of blood vessels

5. Soft tissues around a diarthrodial joint

6. Biofluid and solid interactions

7. Muco-ciliary transport

8. Mathematical biorheology.

\section{Abstract Review:} 1978.

Abstracts will be reviewed on the following dates: 1 February, 1 March, 1 April, 1 May,

Authors will be notified of acceptance or rejection 2 weeks after each of the review dates. Latest date for receipt of abstract by Congress: 1 May, 1978.

Latest notice to authors with regard to selection for presentation: 1 June, 1978.

There is no deadline for submitting full length papers to the Congress for review for possible publication in the journal Biorheology.

\section{PUBLICATION}

Abstracts of symposium lectures and all accepted contributions will be printed in an Abstracts Volume which will be distributed to the participants at the Congress.

Those authors who would like to submit full papers on their contributions to the Society's official journal Biorheology for consideration of possible publication are welcome to do so. These papers will be reyiewed in the normal way according to the Journal's rules. They may be submitted to the Congress office, or to any editor of the Journal. Please write for instructions for preparation of manuscripts. 
LANGUAGE

Official language: English. No arrangements will be made for simultaneous interpretation.

\section{CORRESPONDENCE}

All correspondence concerning the Congress should be sent to:

Dr. John Pinto, Secretary General

The Biorheology Congress

Mail Code M-005

University of California, San Diego

La Jolla, CA 92093

U.S.A. 